\title{
6
}

\section{An Evaluation of Stormwater Management Practices to Provide Flood Protection for Watershed-Based Targets}

\section{Aaron Farrell, John Perdikaris and Ron Scheckenberger}

The Credit River Watershed, within the province of Ontario, measures some $1000 \mathrm{~km}^{2}$, and includes eleven member municipalities. The Watershed has been the subject of many studies and analyses focused on flood management since the early 1980s. Many of these initiatives have served to provide Credit Valley Conservation (CVC) with direction regarding the protection of historically flood prone areas along the main branch of the Credit River (know as Flood Damage Centres), for present and future land use conditions. The most recent initiative undertaken by CVC, termed the Credit River Flow Management Study (FMS), has adopted a watershed-wide assessment approach to flood protection for the main branch Flood Damage Centres. The study process for the FMS has involved using and updating the most current hydrologic and hydraulic models, which have been developed for the Credit River Watershed, in order to evaluate the effectiveness of various stormwater management strategies to provide the requisite flood protection for the Damage Centres, for the anticipated future land use conditions within the Watershed. This has included an evaluation of more traditional and conventional stormwater management practices, a sensitivity analysis of the rainfall distribution, as well as the development of a methodology for the assessment of lot-level Best Management Practices (BMPs) and Low Impact

Farrell, A., J. Perdikaris and R.B. Scheckenberger. 2009. "An Evaluation of Stormwater Management Practices to Provide Flood Protection for Watershed-Based Targets." Journal of Water Management Modeling R235-06. doi: 10.14796/JWMM.R235-06.

(C) CHI 2009 www.chijournal.org ISSN: 2292-6062 (Formerly in Conceptual Modeling of Urban Water Systems. ISBN: 978-0-9808853-2-3) 
Development (LID) systems on a Watershed basis. The FMS has determined that, due to the intrinsic effects of runoff timing, distributed precipitation patterns and runoff volume increases, conventional practices are not suitable for flood control.

\subsection{Introduction}

\subsubsection{Study Context}

The Credit River Watershed is located within the Province of Ontario, along the west shore of Lake Ontario (Figure 6.1). The Watershed measures approximately $1000 \mathrm{~km}^{2}\left(385 \mathrm{mi}^{2}\right)$, and comprises eleven member municipalities and twenty-one subwatersheds. The Watershed is managed by the Credit Valley Conservation (CVC), which operates under a broad mandate to protect lands from adverse flooding and erosion, premised on a watershed management approach (CVC, 2006).

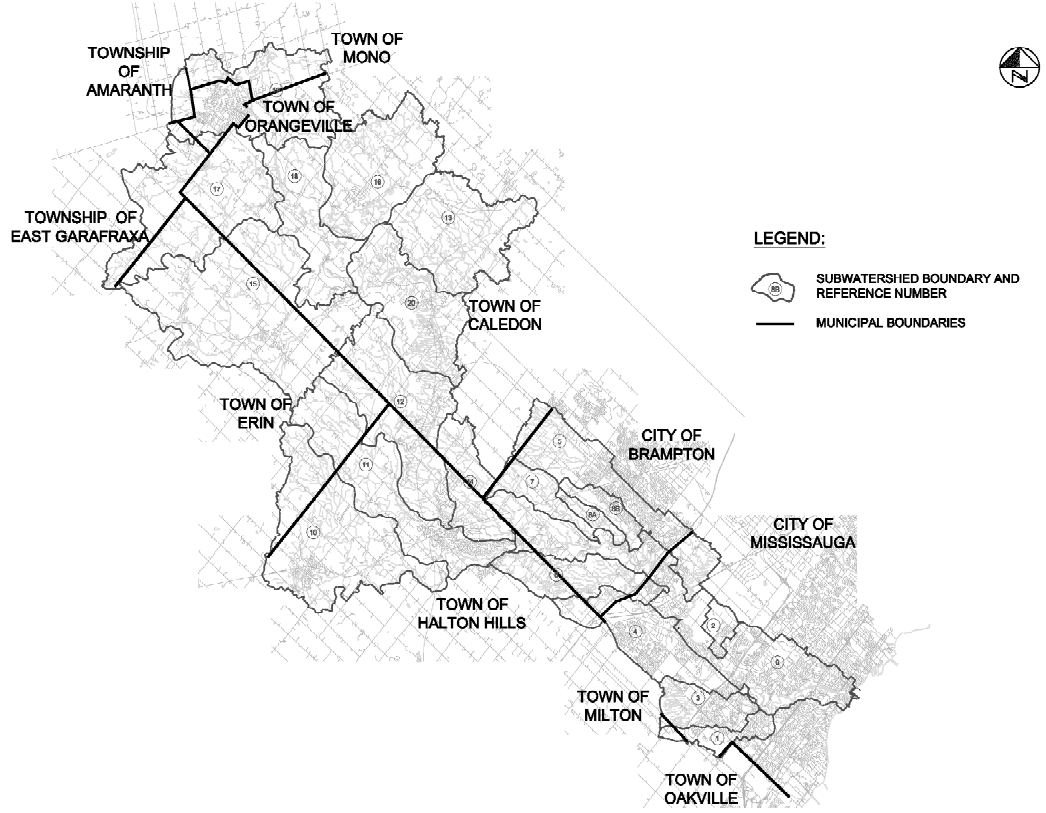

Figure 6.1 Credit River watershed boundary and member municipalities. 
In fulfillment of this mandate, CVC initiated an overall Credit River Water Management Strategy (CRWMS) in 1990, in order to provide direction to local municipalities on land use, environmental and stormwater management implementation. The CRWMS was updated in the mid-2000s (CVC, 2007). The update to the CRWMS consisted of five concurrent studies (Figure 6.2).

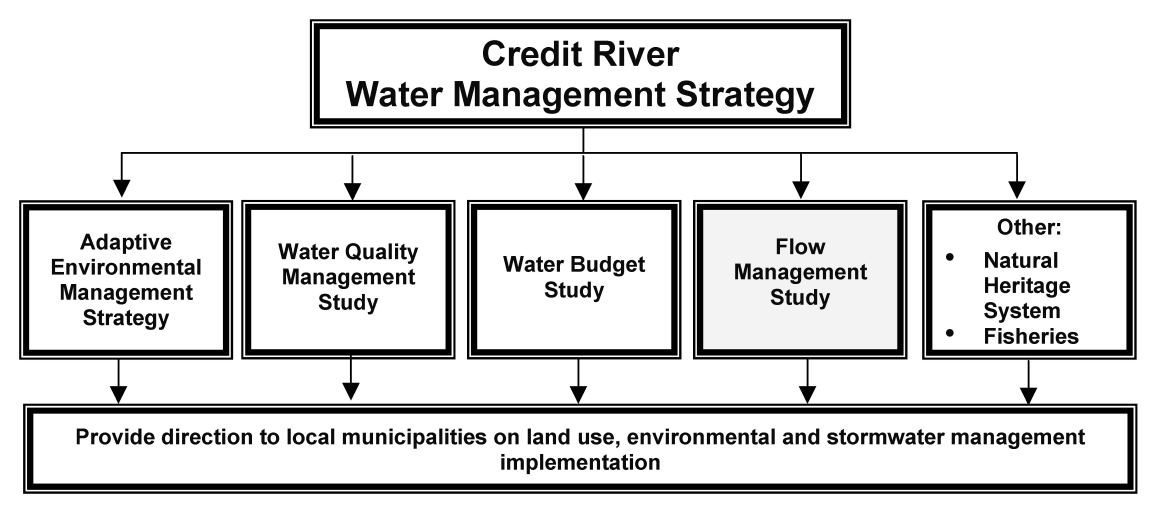

Figure 6.2 Structure of Credit River water management strategy.

As part of the overall Water Management Strategy, CVC initiated the Flow Management Study in order to specifically evaluate the hydrologic impacts of future development during less frequent events which would potentially increase the risk of flooding at strategic locations within the Watershed (Philips Engineering Ltd., 2007).

\subsubsection{Problem Statement}

Previous studies completed for CVC over the past two and a half decades have identified Flood Damage Centres along the main branch of the Credit River, which would be particularly prone to flooding (Figure 6.3). These studies also provided recommendations for providing flood-protection at these locations, which primarily consisted of providing on-site floodproofing, and providing stormwater quantity controls for all future development within the Watershed in order to maintain post-development flow rates to pre-development levels at the tributary outlets to the Credit River Main Branch (Philips Planning and Engineering Ltd., 1984; Triton Engineering, 1990). Observed increases in peak flows in the lower 
watershed were observed through Credit Valley Conservation's ongoing Integrated Watershed Monitoring Program (CVC, 2001).

Despite the application of stormwater quantity controls for future development, peak flow rates along the Credit River main branch were nonetheless observed to increase, particularly at the Damage Centres within the lower reaches of the Credit River. These increased flow rates were also noted to be increasing erosion rates along the Credit River, but were also suspected to be increasing the frequency (and hence the risk) of flooding at the Damage Centres. The Flow Management Study was, therefore, specifically initiated to assess the potential flood risk to the Damage Centres under future development scenarios within the Credit River Watershed, and to evaluate various stormwater management alternatives in order to mitigate the potential increased flood risk to the Damage Centres along the Credit River main branch.

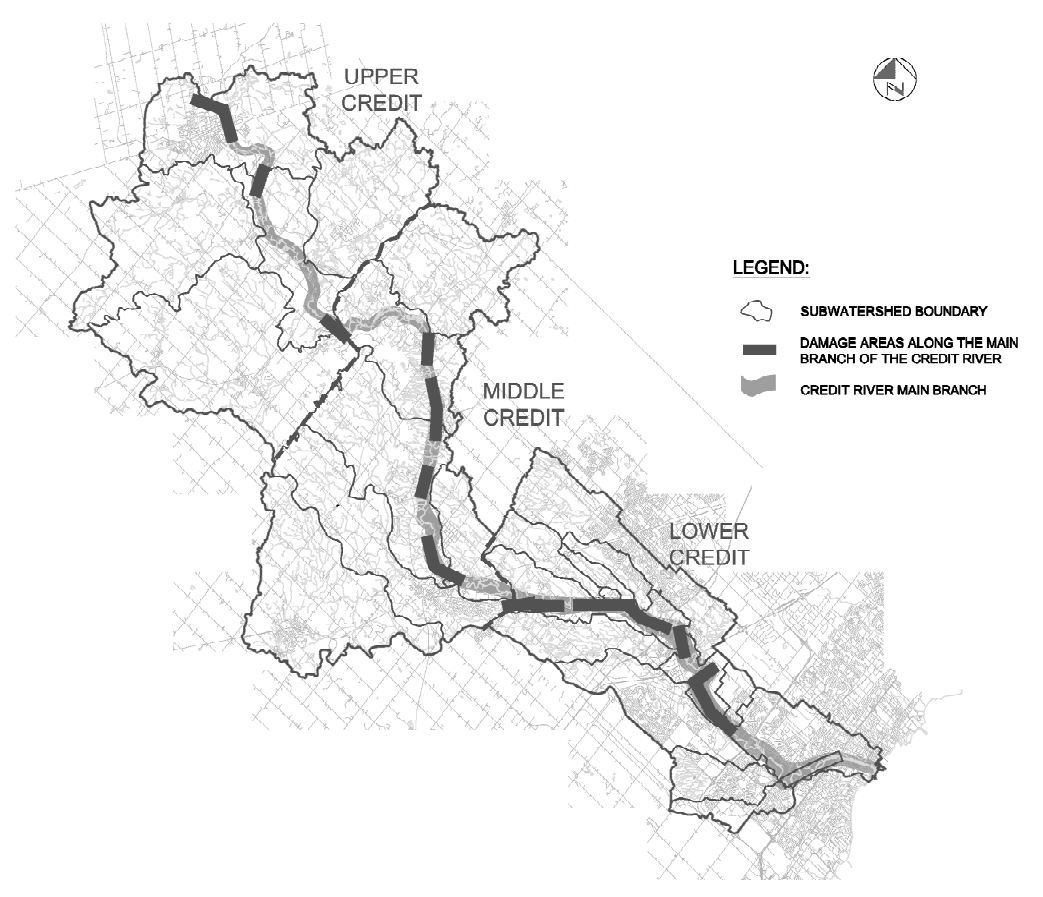

Figure 6.3 Location of damage centres along the Credit River main branch. 


\subsection{Hydrologic Modeling}

\subsubsection{Hydrologic Model Development}

Hydrologic analyses for the Flow Management Study were completed using the Hydrologic Simulation Program-Fortran (HSP-F) hydrologic model. To maintain consistency among the various companion initiatives for the Water Management Strategy, a conventional hydrologic modeling approach was considered for application in the Flow Management Study. The HSP-F model for the Study was developed by areally-weighting the parameters for each lot-level element within the Water Quality Model by the representative amounts of each lot type within each subcatchment [Note: The Water Quality model applied the Unit Response Function methodology at a discrete lot level scale which was considered unsuited to this watershed scale assessment for flooding impacts (City of Toronto WWFMMP, 2003)]. The hydrologic model which was developed based upon this conversion methodology consisted of 125 subcatchments and 146 routing elements for the various reaches and reservoirs within the Watershed (Figure 6.4).

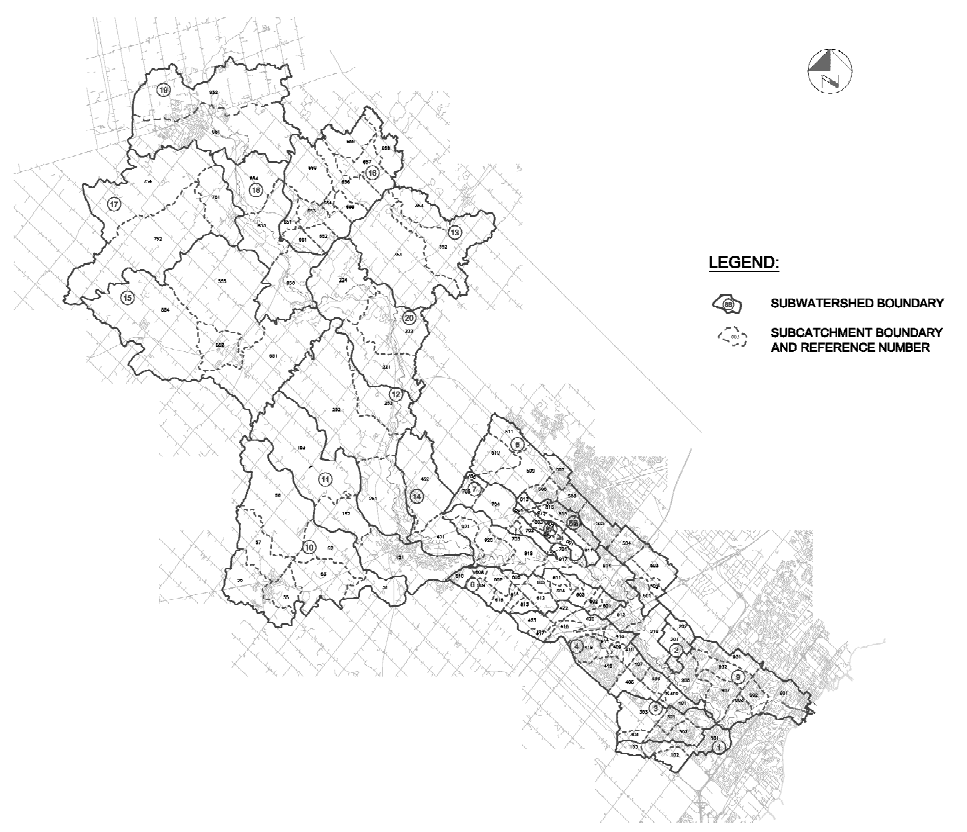

Figure 6.4 Subcatchment boundary plan for HSP-F model of watershed. 
The routing elements along the Credit River main branch were developed based upon current watershed digital elevation models (DEMs). The RiverCAD ${ }^{\mathrm{TM}} / \mathrm{HEC}$-RAS hydraulic modeling program was used to generate hydraulic models from the DEMs, with model cross-sections at $250 \mathrm{~m}$ increments (i.e. 338 cross-sections along the $85 \mathrm{~km}$ length of the Credit River main branch). The hydraulic models were then used to generate the storage-discharge relationships for the various routing elements. The detailed routing elements which were generated using this approach provided travel times of the hydrographs which were consistent with results obtained from other initiatives undertaken by CVC to specifically evaluate this condition within the watershed (EWRG, 2001).

\subsubsection{Model Calibration}

Calibration of the HSP-F hydrologic model for the Flow Management Study was completed using observed precipitation and streamflow data at various monitoring stations within or in the vicinity of the Credit River Watershed (Figure 6.5).

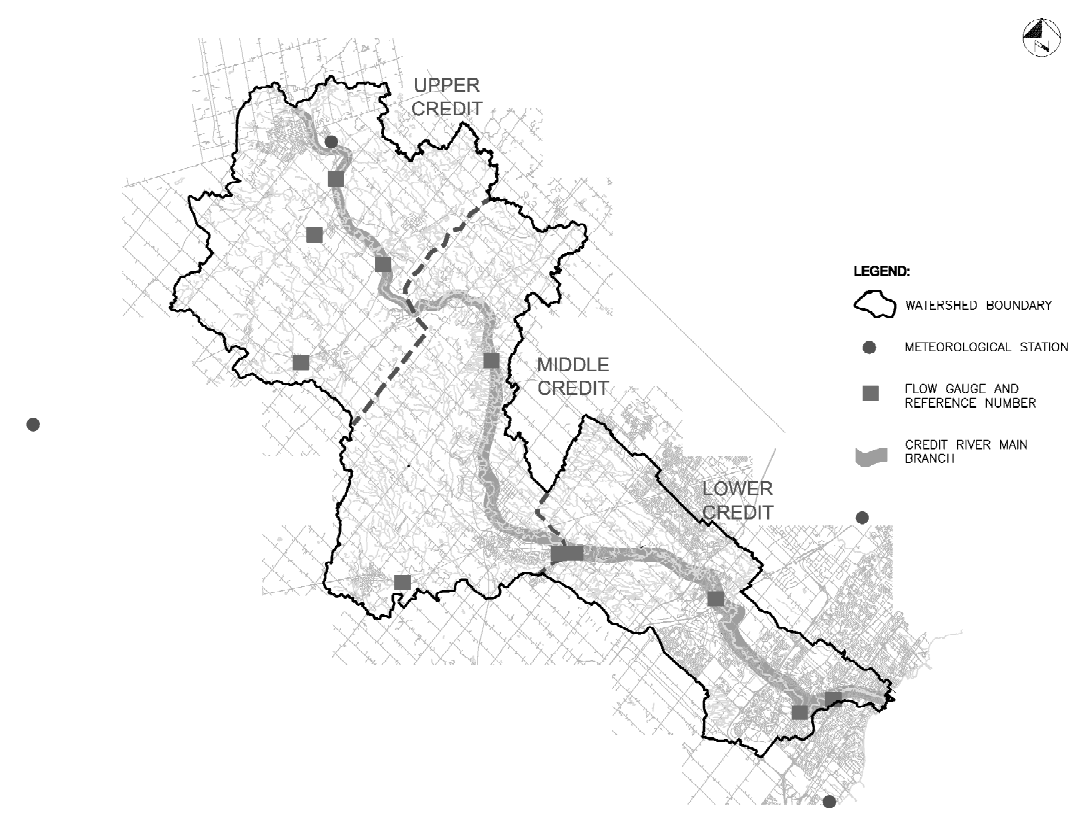

Figure 6.5 Location of streamflow and precipitation gauges for Credit River watershed. 
Due to the size of the watershed, multiple precipitation gauges were recommended for model calibration and continuous simulation, in order to account for the spatial and temporal variability of snow and rainfall across the Watershed. A total of four rainfall gauges are located within, or in the vicinity of the Credit River Watershed with corresponding periods of record for model calibration.

Observed flow data was available at eleven streamflow gauges within the Watershed. Of the eleven gauges, seven were located along the Credit River main branch; since the study focused on evaluating impacts along the Credit River Main branch, the flow data at these seven gauges was selected for model calibration and screened to verify the quality of the information.

A total of 61 events were available, in the form of storm or snowmelt events, which was considered sufficient for the calibration and validation exercise. In the absence of calibration data for the lower reaches of the Credit River main branch, the calibration process consisted of applying the specific parameter adjustment (i.e. weighting) uniformly to all subcatchments within the model, and determining the combination which would yield the "best fit" in terms of peak flow rate and runoff volume (i.e. daily average flow rate) at the four calibration sites.

The HSP-F model was developed for 2001 land use conditions within the watershed. The data provided for model calibration spans 18 years prior to 2001. During this period, much of the development had already occurred, primarily within the lower reaches of the watershed. Thus, the land use conditions within the limits of the gauge data are essentially consistent with the land use conditions for the baseline scenario, and the reliability of the calibrated model would not be affected by land use variations between the baseline condition for the model and the conditions at the time the flow data was obtained.

\subsubsection{Model Sensitivity to Rainfall Distribution}

Previous hydrologic analyses for the watershed were based upon design events, and thus applied rainfall data uniformly across the watershed. The Flow Management Study, however, applied the continuous simulation methodology with multiple precipitation gauges, whereby the calibrated HSP-F hydrologic model was executed for a 40 y continuous simulation, and rainfall data from various locations was distributed across the Credit River Watershed. The application of the continuous simulation methodology and frequency analysis has been observed to produce lower flow rates compared to the event methodology (Farrell et. al., 2001), in part due to the resolution 
of the rainfall data collected for the continuous timeseries versus the resolution of the data generated for storms applying the event methodology (i.e. hourly data versus five minute timesteps); however, it was hypothesized that the application of multiple gauges would further reduce the frequency flows due to the spatial distribution of storm events associated with the application of multiple gauges.

In order to verify this hypothesis, hydrologic analyses were completed for the baseline (2001) land use condition with varying distributions of the rainfall datasets in order to assess the impacts of the spatial and temporal rainfall distributions with respect to the frequency flows at the various Damage Centres. Of the four rainfall gauges used for model calibration, the data provided for three of the gauges was deemed to be of sufficient quality and quantity for application in the continuous simulation. The 2001 land use conditions model was thus executed using the following rainfall dataset distributions:

- Three rainfall gauges,

- Two rainfall gauges (one for the upper reaches and one for the lower reaches), and

- One rainfall gauge applied uniformly across the watershed.

Frequency analyses were completed using the Log Pearson Type III Distribution, based upon the simulated annual maximum flow rates. The results are presented in Table 6.1.

The results in Table 6.1 indicate that the frequency flows at the Damage Centres within the lower reaches of the Credit River Watershed are the only ones affected by the distribution of the two precipitation gauges as opposed to the original three rainfall gauges; this is because the same rainfall data was applied for the subcatchments discharging within the upper headwater and middle reaches of the watershed under both the two and three gauge scenario. The results in Table 6.1 also demonstrate that the frequency flows at the Damage Centres within the lower reaches of the Credit River are particularly sensitive to the number of rainfall datasets applied for the continuous simulation, and that the frequency flow rates would be anticipated to increase with a reduction in the number of rainfall gauges. The foregoing assessment confirmed the hypothesis that the flow rates along the Credit River main branch are sensitive to the spatial and temporal variability in the rainfall data, and suggest that the higher flow rates obtained in previous studies could be attributed to the uniform application of rainfall data across the watershed. On this basis, it was considered prudent to retain the spatial and temporal variability in the meteorological dataset, but at the 
same time to incorporate a certain degree of conservativeness into the hydrologic analyses. For this reason, two rainfall datasets were applied for the continuous simulation in the hydrologic analyses.

Table 6.1 Frequency flows for 2001 land use conditions for different precipitation datasets (Log Pearson Type III distribution). $\left(\mathrm{m}^{3} / \mathrm{s}\right)$

\begin{tabular}{|c|c|c|c|c|}
\hline \multirow{2}{*}{ Damage centre location } & \multicolumn{4}{|c|}{ Frequency (years) } \\
\hline & 10 & 20 & 50 & 100 \\
\hline \multicolumn{5}{|c|}{ Three rainfall gauges } \\
\hline \multicolumn{5}{|c|}{ Upper headwater reaches of Credit River } \\
\hline Middle reaches of Credit River watershed & 72.7 & 89.0 & 111 & 127 \\
\hline Lower reaches of Credit River watershed & 118 & 143 & 179 & 208 \\
\hline \multicolumn{5}{|c|}{ Two rainfall gauges } \\
\hline $\begin{array}{l}\text { Upper headwater reaches of Credit River } \\
\text { watershed }\end{array}$ & 17.8 & 21.6 & 26.8 & 31.0 \\
\hline Middle reaches of Credit River watershed & 72.7 & 89.0 & 111 & 127 \\
\hline Lower reaches of Credit River watershed & 118 & 146 & 186 & 219 \\
\hline \multicolumn{5}{|c|}{ One rainfall gauge } \\
\hline $\begin{array}{l}\text { Upper headwater reaches of Credit River } \\
\text { watershed }\end{array}$ & 23.8 & 32.6 & 48.4 & 64.6 \\
\hline Middle reaches of Credit River watershed & 74.8 & 87.1 & 101 & 110 \\
\hline Lower reaches of Credit River watershed & 131 & 162 & 208 & 246 \\
\hline
\end{tabular}

\subsubsection{Land Use Conditions}

Land use conditions within the watershed were provided for the years 2001 (the baseline condition), and for 2051. The land use conditions for 2051 were developed based upon current Official Plans for the member municipalities, and were also predicated upon any future development beyond the Official Plans occurring primarily within areas which are currently urbanized and therefore provide stormwater, water, and sanitary servicing; this premise is also consistent with the principles applied in current Provincial Policies regarding urban expansion and planning, such as the Places to Grow Act. In addition, two other land use scenarios were developed based upon the land use conditions provided in the 2001 and 2051 scenarios. The first of these scenarios represented a "Low Stressor" condition within the watershed, whereby the additional impervious coverage for each subcatchment beyond the 2001 scenario was $50 \%$ of the additional impervious coverage under the 2051 scenario. The second of these scenarios 
represented a "High Stressor" condition within the watershed, whereby the additional impervious coverage for each subcatchment, beyond the 2001 scenario was $50 \%$ greater than the additional impervious coverage under the 2051 scenario. The Low and High Stressor scenarios were considered to represent varying degrees of urban intensification, as well as potential interim and ultimate development scenarios within the watershed. The additional impervious coverage for each subwatershed within the Credit River Watershed, under Low Stressor, 2051, and High Stressor land use conditions, are presented in Figures 6.6, 6.7, and 6.8 respectively.

The information presented in Figures 6.6, 6.7, and 6.8 indicates that the future development within the Credit River watershed would be concentrated primarily within the lower reaches of the watershed, with relatively minor amounts of development occurring within the headwaters and none anticipated within the middle reaches of the watershed.

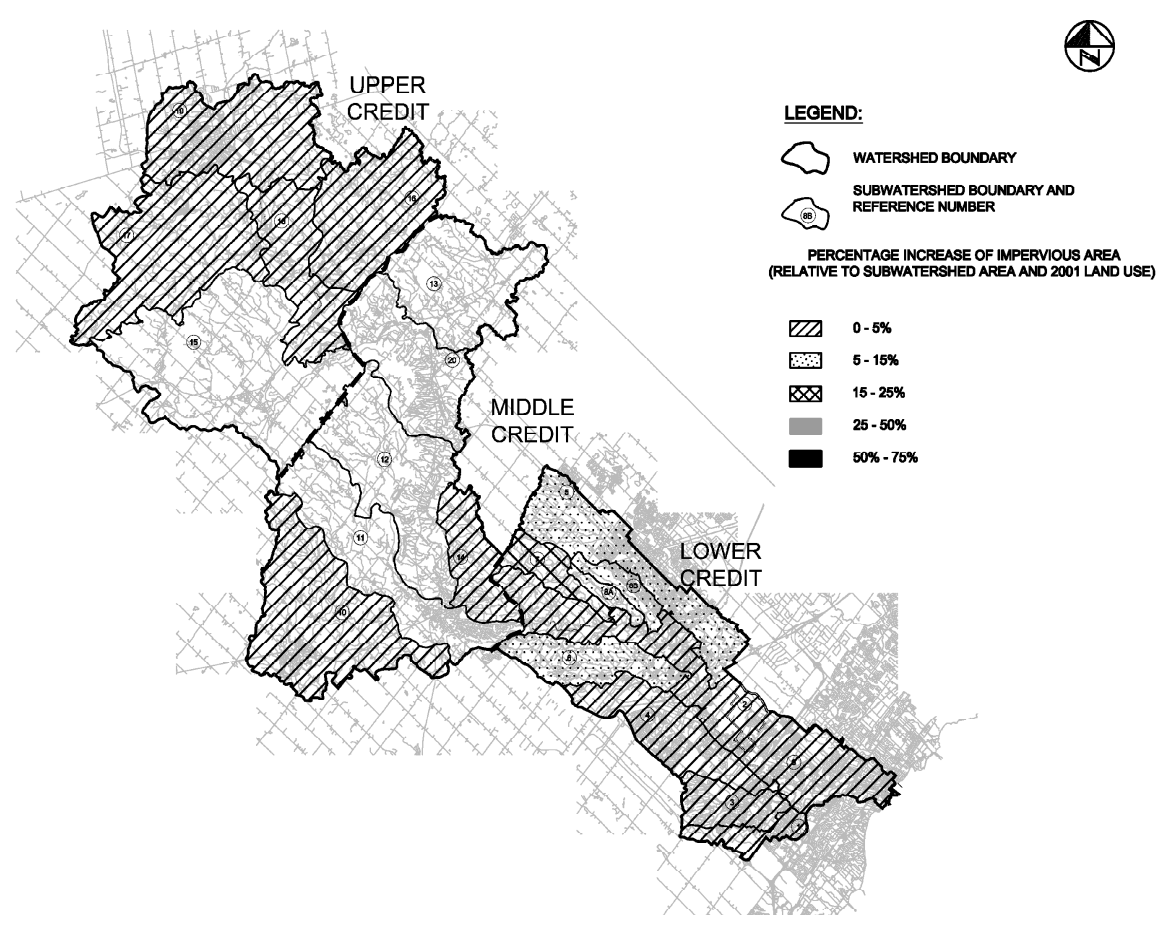

Figure 6.6 Increase in impervious cover for Credit River watershed for low stressor scenario. 


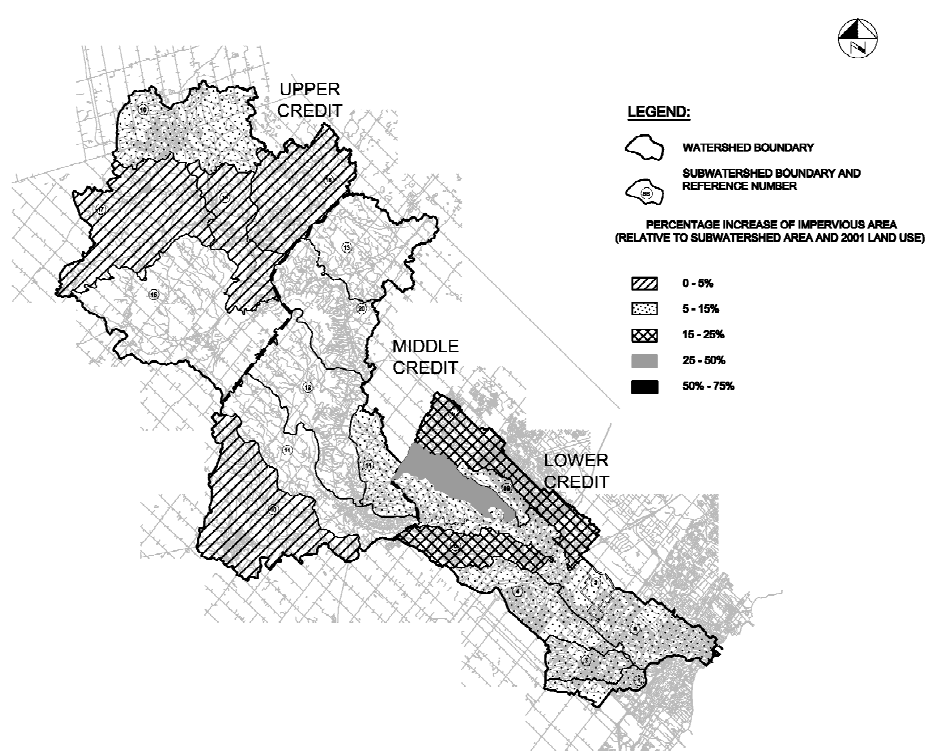

Figure 6.7 Increase in impervious cover from 2001 to 2051.

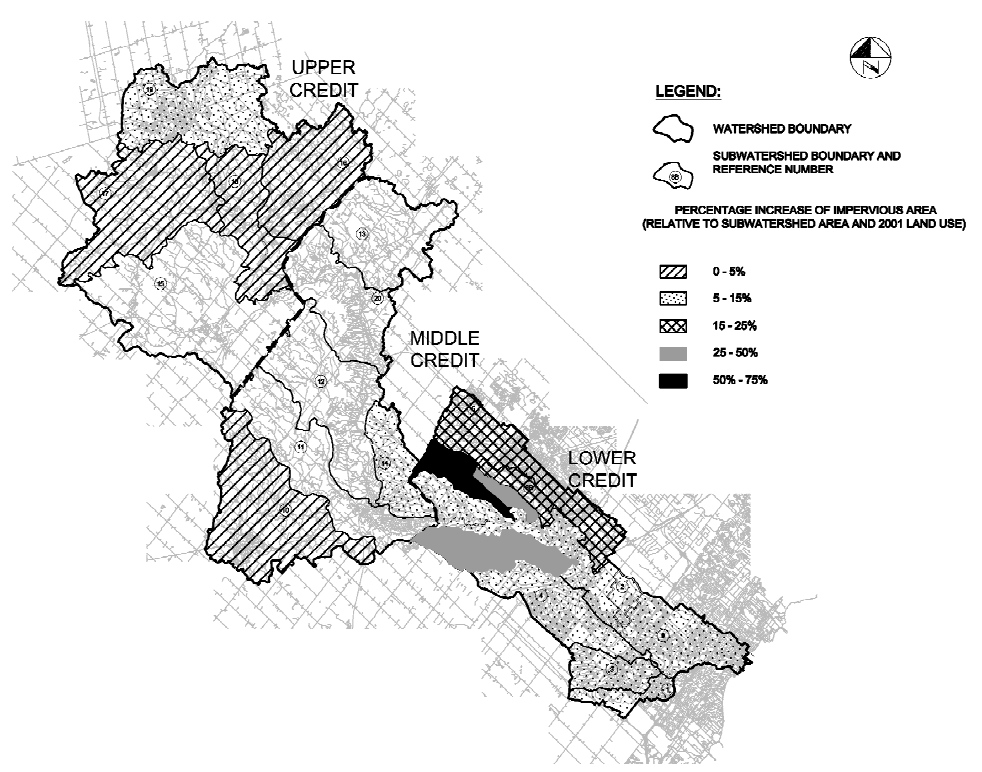

Figure 6.8 Increase in impervious cover for high stressor scenario. 


\subsection{Hydrologic Analyses}

The HSP-F hydrologic models which were developed for the 2001 land use conditions, as well as for the future land use scenarios without stormwater quantity controls, were executed for a 40 y continuous simulation, and frequency analyses were completed at each of the Damage Centres located along the Credit River main branch based upon the simulated annual maximum flow rates; for the Damage Centres within the lower reaches of the Credit River Watershed, the General Extreme Value Distribution was found to provide a trendline fit to the data which was most representative of the results for all stormwater management scenarios, and was thus applied for the frequency analyses at the Damage Centres within the lower reaches. The results at representative locations with the Credit River Watershed are summarized in Table 6.2.

Table 6.2 Frequency flows for 2001 land use conditions and future land use conditions without stormwater management. $\left(\mathrm{m}^{3} / \mathrm{s}\right)$

\begin{tabular}{|c|c|c|c|c|}
\hline \multirow[t]{2}{*}{ Damage Centre Location } & \multicolumn{4}{|c|}{ Frequency (years) } \\
\hline & 10 & 20 & 50 & 100 \\
\hline \multicolumn{5}{|c|}{2001 Land use conditions. } \\
\hline $\begin{array}{l}\text { Upper headwater reaches of Credit River } \\
\text { watershed }\end{array}$ & 17.8 & 21.6 & 26.8 & 31.0 \\
\hline Middle reaches of Credit River watershed & 72.7 & 89.0 & 111 & 127 \\
\hline Lower reaches of Credit River watershed & 118 & 141 & 171 & 195 \\
\hline \multicolumn{5}{|c|}{ Low stressor land use conditions without stormwater management. } \\
\hline $\begin{array}{l}\text { Upper headwater reaches of Credit River } \\
\text { watershed }\end{array}$ & 22.4 & 26.9 & 33.2 & 38.4 \\
\hline Middle reaches of Credit River watershed & 73.5 & 87.3 & 104 & 115 \\
\hline Lower reaches of Credit River watershed & 127 & 151 & 187 & 215 \\
\hline \multicolumn{5}{|c|}{2051 Land use conditions without stormwater management. } \\
\hline $\begin{array}{l}\text { Upper headwater reaches of Credit River } \\
\text { watershed }\end{array}$ & 27.3 & 33.1 & 41.5 & 48.6 \\
\hline Middle reaches of Credit River watershed & 74.4 & 89.6 & 109 & 122 \\
\hline Lower reaches of Credit River watershed & 138 & 166 & 206 & 237 \\
\hline \multicolumn{5}{|c|}{ High stressor land use conditions without stormwater management. } \\
\hline $\begin{array}{l}\text { Upper headwater reaches of Credit River } \\
\text { watershed }\end{array}$ & 32.5 & 39.7 & 50.6 & 60.1 \\
\hline Middle reaches of Credit River watershed & 76.2 & 92.3 & 113 & 128 \\
\hline Lower reaches of Credit River watershed & 152 & 183 & 227 & 263 \\
\hline
\end{tabular}


The results of the foregoing assessment indicate that the frequency flows at the Damage Centres within the Lower Credit River Watershed, as well as the Damage Centres within headwaters of the watershed tend to be sensitive to changes in impervious coverage for the development areas identified under the 2051 land use scenario; by comparison, the frequency flows at the Damage Centres within the Middle Credit River Watershed are considered relatively insensitive to the levels of imperviousness considered under this scenario. This is due to the locations of intensive development under the 2051 land use scenario previously mentioned, which are primarily within the Lower Credit River Watershed.

\subsubsection{Stormwater Management Strategy Assessment}

\section{"Business as Usual"}

Conventional stormwater management practice would consist of controlling post-development flow rates to pre-development levels at the outlets of each subwatershed tributary to the Credit River, and for each subcatchment traversed by the Credit River main branch. The HSP-F hydrologic model for 2051 land use conditions was updated to include stormwater management controls at each outlet to the Credit River Watershed from lands which would be developed under the respective future land use scenarios. The stormwater management facilities within the subwatersheds were simulated as a single system at the outlet, rather than incorporating separate facilities at each subcatchment which would be developed. Although this approach provides a less refined assessment than would be obtained by incorporating facilities for each subcatchment, the methodology is considered suitable for a watershed-scale assessment within the Credit River Watershed, and would reflect the combined impacts associated with the implementation of several stormwater quantity control facilities (i.e. reduction in peak flow rate and lag in time to peak).

The respective storage-discharge relationships were incorporated into the HSP-F hydrologic models for future land use conditions. The models were run for a 40 y continuous simulation and frequency analyses were completed at the Damage Centres along the Credit River main Branch based upon the simulated annual maximum flow rates. The simulated frequency flows at representative locations are summarized in Table 6.3 and the \% increase compared to 2001 land use conditions are summarized in Table 6.4.

Compared with the results presented for future uncontrolled land use conditions, the results in Table 6.3 indicate that the application of 
conventional post-to-pre control for future development areas would reduce peak flow rates at the Damage Centres along the Credit River Main Branch compared to future land use conditions without stormwater management. Nevertheless, the results of the foregoing assessment indicate that increased flow rates at the Damage Centres particularly along the lower reaches of the Credit River Main Branch, would be anticipated compared to 2001 land use conditions, despite the application of conventional quantity controls to maintain post-development flow rates to pre-development levels at the subwatershed outlets.

Table 6.3 Frequency flows for future land use conditions with "business as usual" stormwater management. $\left(\mathrm{m}^{3} / \mathrm{s}\right)$

\begin{tabular}{|c|c|c|c|c|}
\hline \multirow[t]{2}{*}{ Damage centre location } & \multicolumn{4}{|c|}{ Frequency (years) } \\
\hline & 10 & 20 & 50 & 100 \\
\hline \multicolumn{5}{|c|}{$\begin{array}{c}\text { Low stressor land use conditions with "business as usual" } \\
\text { stormwater management. }\end{array}$} \\
\hline $\begin{array}{l}\text { Upper headwater reaches of Credit River } \\
\text { watershed }\end{array}$ & 17.3 & 21.1 & 26.5 & 30.9 \\
\hline Middle reaches of Credit River watershed & 73.3 & 87.1 & 104 & 115 \\
\hline Lower reaches of Credit River watershed & 126 & 15 & 185 & 212 \\
\hline \multicolumn{5}{|c|}{$\begin{array}{l}2051 \text { Land use conditions with "business as usual" } \\
\text { stormwater management. }\end{array}$} \\
\hline $\begin{array}{l}\text { Upper headwater reaches of Credit River } \\
\text { watershed }\end{array}$ & 17.7 & 21.5 & 26.8 & 31.1 \\
\hline Middle reaches of Credit River watershed & 74.0 & 89.2 & 108 & 121 \\
\hline Lower reaches of Credit River watershed & 130 & 157 & 194 & 224 \\
\hline \multicolumn{5}{|c|}{$\begin{array}{c}\text { High stressor land use conditions with "business as usual" } \\
\text { stormwater management. }\end{array}$} \\
\hline $\begin{array}{l}\text { Upper headwater reaches of Credit River } \\
\text { watershed }\end{array}$ & 18.2 & 21.9 & 27.0 & 31.0 \\
\hline Middle reaches of Credit River watershed & 75.6 & 91.5 & 112 & 127 \\
\hline Lower reaches of Credit River watershed & 133 & 162 & 202 & 234 \\
\hline
\end{tabular}

The results of the foregoing assessment also indicate that the peak flow rates at the Damage Centres along the Credit River Main Branch are sensitive to the impervious coverage within the future development areas, 
despite the control of post-development flows to pre-development (2001) levels for all future land use conditions.

Table $6.4 \%$ Increase in frequency flow future land use conditions with "business as usual" stormwater management.

\begin{tabular}{|c|c|c|c|c|}
\hline \multirow[t]{2}{*}{ Damage centre location } & \multicolumn{4}{|c|}{ Frequency (years) } \\
\hline & 10 & 20 & 50 & 100 \\
\hline \multicolumn{5}{|c|}{$\begin{array}{c}\text { Low stressor land use conditions with "business as usual" } \\
\text { stormwater management. }\end{array}$} \\
\hline $\begin{array}{l}\text { Upper headwater reaches of Credit River } \\
\text { watershed }\end{array}$ & -3 & -2 & -1 & 0 \\
\hline Middle reaches of Credit River watershed & 1 & -2 & -6 & -9 \\
\hline Lower reaches of Credit River watershed & 7 & 7 & 8 & 9 \\
\hline \multicolumn{5}{|c|}{$\begin{array}{c}2051 \text { Land use conditions with "business as usual" } \\
\text { stormwater management. }\end{array}$} \\
\hline $\begin{array}{l}\text { Upper headwater reaches of Credit River } \\
\text { watershed }\end{array}$ & -1 & 0 & 0 & 0 \\
\hline Middle reaches of Credit River watershed & 2 & 0 & -3 & -5 \\
\hline Lower reaches of Credit River watershed & 10 & 11 & 13 & 15 \\
\hline \multicolumn{5}{|c|}{$\begin{array}{c}\text { High stressor land use conditions with "business as usual" } \\
\text { stormwater management. }\end{array}$} \\
\hline $\begin{array}{l}\text { Upper headwater reaches of Credit River } \\
\text { watershed }\end{array}$ & 2 & 1 & 1 & 0 \\
\hline Middle reaches of Credit River watershed & 4 & 3 & 1 & 0 \\
\hline Lower reaches of Credit River watershed & 13 & 15 & 18 & 20 \\
\hline
\end{tabular}

Simulated hydrographs within the lower reaches of the Credit River watershed were extracted from the model and compared in order to further assess this condition. The hydrographs for Subwatershed 6 under 2001 and 2051 land use conditions, with and without conventional stormwater quantity controls, were obtained since Subwatershed 6 was predicted to have a high increase in development (i.e. impervious area) under future land use conditions. The hydrographs for the Credit River main branch upstream and downstream of the confluence with the Subwatershed 6 outlet were extracted (Figure 6.9). 


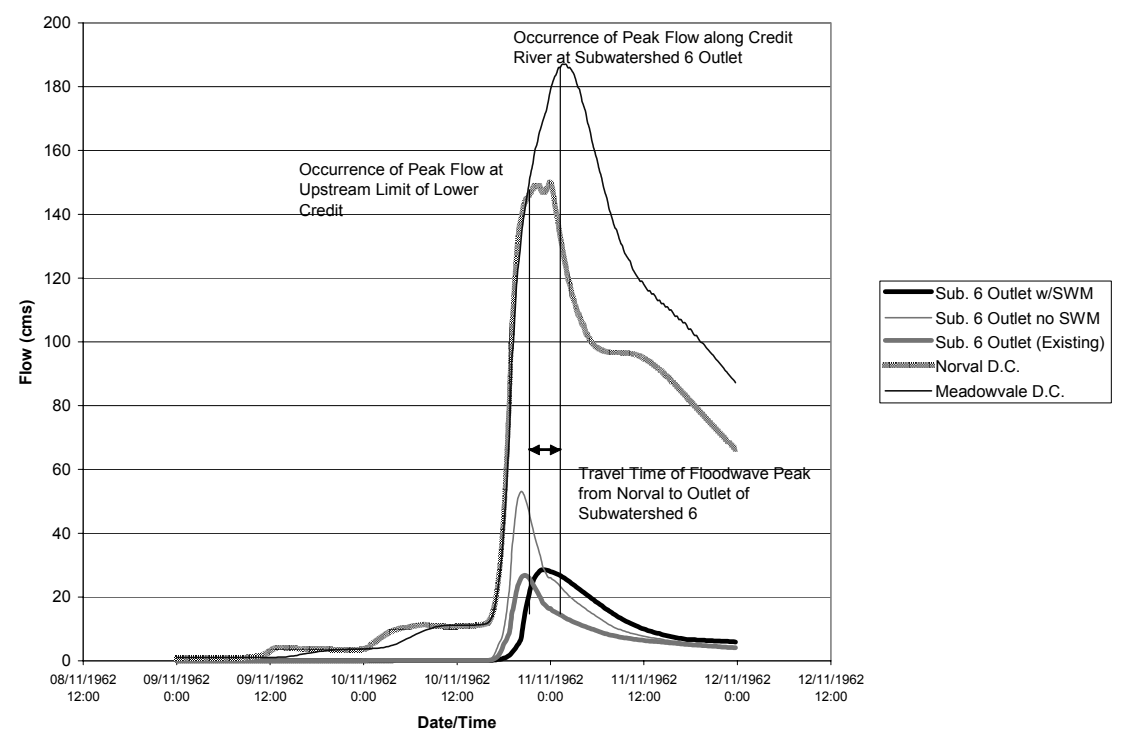

Figure 6.9 Comparison of hydrographs within lower reaches of Credit River Watershed.

The results in Figure 6.9 indicate that under future uncontrolled conditions, the hydrograph would be anticipated to exhibit a higher peak flow rate and runoff volume, but a shorter time to peak compared to the hydrograph under existing land use conditions; this is consistent with observations documented in other sources for the impacts of urban development. The results also indicate that under future land use conditions, with conventional stormwater quantity control, the application of stormwater management would reduce the peak flow rate to pre-development levels, but there would be no reduction in runoff volume compared to future uncontrolled land use conditions, and the time to peak would be increased compared to pre-developed land use conditions. Of most significance, the results indicate that the increased time to peak under future land use conditions with stormwater management would result in more coincident peak flow rates on-line with the Credit River Main Branch as well as at the subwatershed outlet; hence, although the peak flow rate would be reduced to pre-development levels through the application of conventional stormwater management, the lagging effect associated with the application of conventional stormwater management applied to urban areas, and the near, 
or total, coincidence with the time to peak for the more rurally-based flood wave along the Credit River Main Branch would result in increased peak flow rates along the Credit River Main Branch compared to baseline conditions. On this basis, the conventional practice of applying stormwater quantity controls was shown to be ineffective in maintaining flood protection (i.e. reducing peak flow rates) at all watershed targets.

\section{Strategic Over/Under Control}

Once it was recognized that the timing of peak flow rates within the lower reaches of the Credit River Watershed was a significant factor in providing quantity control at the on-line Damage Centres, alternative stormwater management strategies were evaluated, affecting both peak flow rates and the times to peak within the tributary subwatersheds and/or along the Credit River Main Branch. The following strategies were evaluated:

- Under/Partial Control: under this strategy, stormwater management controls within the Lower Credit River Watershed would provide post-to-pre control for storm events up to approximately the 20 y frequency, and flows more severe than that frequency would be released uncontrolled to the local receiving watercourses; thus, peak flows for the more severe events in the lower watershed would discharge to the main branch without any substantive attenuation or lag, and thereby in theory not coincide with the timing of the upstream flood wave, thus reducing in-stream peak flows on the main branch.

- Over Control in the Lower Credit: under this strategy, the post-development peak flows at the subwatershed outlets within the Lower Credit River Watershed would be reduced to below pre-development (2001) levels by increasing the storage volumes within the facilities compared to that which would be required under the "Business As Usual" strategy.

- Supplemental Flow Control Works: under this strategy, peak flows along the Credit River Main Branch would be controlled via a system of centralized storage units along the main branch, to complement locally applied stormwater management practices. 
Hydrologic analyses were completed for each of these strategies, in order to gain insight into the potential effectiveness of these alternatives; thus, analyses were completed for the 2051 land use scenario only.

\section{Under/Partial Control}

Under/partial control for stormwater management represents a form of strategic stormwater quantity control, whereby the stormwater management facilities for the future development areas within the Lower Credit River Watershed would be sized to provide post-to-pre control for events up to approximately the twenty year frequency, with events above the twenty year frequency being released essentially uncontrolled to the receiving watercourse; conventional post-to-pre control would be provided for future development within the Upper and Middle Credit River Watershed.

The simulated frequency flows for the 2051 land use conditions under this stormwater management strategy are summarized in Table 6.5, and the $\%$ increase compared to 2001 land use conditions are summarized in Table 6.6.

Table 6.5 Frequency flows for 2051 land use conditions with under/partial control stormwater management. $\left(\mathrm{m}^{3} / \mathrm{s}\right)$

\begin{tabular}{lcccc}
\hline Damage centre location & \multicolumn{4}{c}{ Frequency (years) } \\
& 10 & 20 & 50 & 100 \\
\hline Upper headwater reaches of Credit River & 17.7 & 21.5 & 26.8 & 31.1 \\
watershed & 74.0 & 89.2 & 108 & 121 \\
Middle reaches of Credit River watershed & 130 & 158 & 195 & 225 \\
Lower reaches of Credit River watershed & & & \\
\hline
\end{tabular}

Table $6.6 \%$ Increase in frequency flow 2051 land use conditions with under/partial control stormwater management.

\begin{tabular}{lcccc}
\hline Damage centre location & \multicolumn{4}{c}{ Frequency (years) } \\
& 10 & 20 & 50 & 100 \\
\hline Upper headwater reaches of Credit River & -1 & 0 & 0 & 0 \\
watershed & 2 & 0 & -3 & -5 \\
Middle reaches of Credit River watershed & 10 & 12 & 14 & 15 \\
Lower reaches of Credit River watershed & &
\end{tabular}


Compared with the results presented in Table 6.4, the results in Table 6.6 indicate that the application of under/partial quantity control for storm runoff within the Lower Credit River Watershed would nominally affect the peak flow rates at the Damage Centres along the Credit River Main Branch compared to "Business As Usual". Moreover, the results indicate that the frequency flows at the Damage Centres would remain above the targets identified in the 2001 land use scenario. Although additional analyses could be completed in order to determine whether or not an "optimal" level of partial control could be achieved, the feasibility of implementing this alternative presents a logistical issue, since it is contingent upon the local hydraulic constraints imposed by the existing watercourses, hydraulic structures, and infrastructure downstream of the future development areas, and inherently assumes, possibly incorrectly, that the existing infrastructure within the subwatersheds in the lower Credit River Watershed would provide sufficient capacity to accommodate the increased flow rates associated with this strategy.

\section{Over-Control in the Lower Credit}

Hydrologic analyses were completed for full over-control of runoff from future development areas within the Lower Credit River Watershed and conventional post-to-pre control within the Upper and Middle Credit River Watersheds. The unitary storage requirements for the stormwater management facilities within the Lower Credit River Watershed were increased by $50 \%$ compared to the "Business As Usual" scenario, in order to determine whether or not this increase would provide an appreciable reduction to the peak flow rates along the Credit River Main Branch. The simulated frequency flows for the 2051 land use conditions under this stormwater management alternative are summarized in Table 6.7, and the $\%$ increase compared to 2001 land use conditions is summarized in Table 6.8.

Table 6.7 Frequency flows for 2051 land use conditions with over control stormwater management. $\left(\mathrm{m}^{3} / \mathrm{s}\right)$

\begin{tabular}{lcccc}
\hline Damage centre location & \multicolumn{4}{c}{ Frequency (years) } \\
& 10 & 20 & 50 & 100 \\
\hline Upper headwater reaches of Credit River & 17.7 & 21.5 & 26.8 & 31.1 \\
watershed & 74.0 & 89.2 & 108 & 121 \\
Middle reaches of Credit River watershed & 125 & 151 & 187 & 215 \\
Lower reaches of Credit River watershed & & & \\
\hline
\end{tabular}


The results in Table 6.8 indicate that the addition of $50 \%$ more detention storage volume to the stormwater management facilities within the Lower Credit River Watershed would not reduce post-development flows to predevelopment levels at the Damage Centres along the Credit River Main Branch within the Lower Credit River Watershed.

Table $6.8 \%$ Increase in frequency flow 2051 land use conditions with over control stormwater management.

\begin{tabular}{lcccc}
\hline & \multicolumn{2}{c}{ Frequency (years) } & & \\
& 10 & 20 & 50 & 100 \\
\hline Upper headwater reaches of Credit River & -1 & 0 & 0 & 0 \\
watershed & 2 & 0 & -3 & -5 \\
Middle reaches of Credit River watershed & 6 & 7 & 9 & 10 \\
Lower reaches of Credit River watershed & 6 &
\end{tabular}

Supplemental Flow Control Works

Under this scenario, the conventional "Business As Usual" stormwater management strategy for all future development would be complemented by an on-line impoundment area along the Credit River Main Branch located toward the lower end of the Middle Credit River Watershed. This supplemental on-line facility, in theory, would be targeted at protecting downstream areas against "severe" event flooding (i.e. 20 y event or greater), and would utilize natural floodplain storage above the bankfull condition to create attenuation and lag in the Main Branch hydrograph, thereby delaying the time to peak with respect to the peaks at the downstream subwatershed outlets and reducing the overall peak flow rates along the Credit River Main Branch. Based upon a review of the available mapping, a preliminary candidate site was located toward the outlet of the middle reaches of the Credit River Watershed. A $300,000 \mathrm{~m}^{3}$ storage element was incorporated into the hydrologic model for the 2051 land use condition developed for the "Business As Usual" scenario, and the model run for the 40 y continuous simulation. The simulated frequency flows for the future land use conditions under this stormwater management alternative are summarized in Table 6.9, and the \% increase compared to 2001 land use conditions are summarized in Table 6.10.

The results of this assessment suggest that an on-line impoundment area would provide a reduction in peak flows when compared to "Business As Usual", in the absence of this supplemental facility; nevertheless, the frequency flows would remain above pre-development levels. This 
alternative also presented additional logistical issues, since the implementation of any on-line quantity control system would need to address environmental constraints (i.e. impacts on fish passage, stream morphology, and terrestrial systems), functional constraints (i.e. potential impacts on upstream flood elevations), social issues (i.e. possible land ownership issues, along with loss of use post flooding), economics (i.e. cost of retrofitting existing structures or constructing new "stand-alone" facilities) and staging for implementation (i.e. determining the "critical time" at which the construction of on-line systems would be required in order to support additional development). Thus, although this alternative could conceivably contribute to the requisite post-to-pre control at the Damage Centres along the Credit River Main Branch, the logistical issues identified above (which remain to be resolved), preclude this from being a readily viable solution.

Table 6.9 Frequency flows for 2051 land use conditions with "business as usual" stormwater management and supplemental flood control facility. $\left(\mathrm{m}^{3} / \mathrm{s}\right)$

\begin{tabular}{lcccc}
\hline Damage centre location & \multicolumn{4}{c}{ Frequency (years) } \\
& 10 & 20 & 50 & 100 \\
\hline Upper headwater reaches of Credit River & 17.7 & 21.5 & 26.8 & 31.1 \\
watershed & 74.0 & 89.2 & 108 & 121 \\
Middle reaches of Credit River watershed & 128 & 154 & 190 & 218 \\
Lower reaches of Credit River watershed & & &
\end{tabular}

Table $6.10 \%$ Increase in frequency flow 2051 land use conditions with "business as usual" stormwater management and supplemental flood control facility

\begin{tabular}{lcccc}
\hline Damage centre location & \multicolumn{4}{c}{ Frequency (years) } \\
& 10 & 20 & 50 & 100 \\
\hline Upper headwater reaches of Credit River & -1 & 0 & 0 & 0 \\
watershed & 2 & 0 & -3 & -5 \\
Middle reaches of Credit River watershed & 8 & 9 & 11 & 12 \\
Lower reaches of Credit River watershed & 8 &
\end{tabular}

\section{Ecotopia}

The Credit River Water Management Strategy Update (CRWMSU) included an assessment of an idealistic future land use condition termed "Ecotopia". This combined land use and stormwater management condition considers aggressive application of lot level/source best management practices (BMPs) for stormwater management for $100 \%$ of future developing areas. It also 
assumes a "moderate" level of uptake of similar BMPs for the existing developed areas (15\%) in the form of retrofits. The HSP-F hydrologic model for the 2051 land use condition was modified in order to incorporate the lotlevel BMPs associated with the Ecotopia scenario.

Various lot-level BMPs have been documented previously (MOE, 2003), however no direction for simulating the partial application of these practices as a "lumped" subcatchment representing urban areas with and without BMPs could be determined within the available literature. Following a thorough review of the HSP-F manual, various techniques for simulating lotlevel BMPs at the subcatchment scale were derived; these are summarized in Table 6.11.

The simulation techniques specified in Table 6.11 would incorporate the hydrologic effects of the Ecotopia strategy specifically related to reductions in runoff volumes through the various interception storages and infiltration techniques.

The simulation techniques specified in Table 6.11 would incorporate the hydrologic effects of the Ecotopia strategy specifically related to reductions in runoff volumes through the various interception storages and infiltration techniques and thereby maintaining the natural rainfall-runoff relationship (Zimmer, 2006; Pitt et. al. 2005).

Table 6.11 Summary of simulation techniques for ecotopia.

\begin{tabular}{ll}
\hline Technology & Simulation technique \\
\hline Roof storage/ponds & $\begin{array}{l}\text { Increase interception storage for impervious land uses. The } \\
\text { additional depth of interception storage was determined based } \\
\text { upon the storage volume and rooftop storage area specified in the } \\
\text { Water Quality Model, and weighted according to the amount of } \\
\text { the overall impervious area draining to these systems. } \\
\text { Etobicoke exfiltration } \\
\text { systems (EES) }\end{array}$ \\
$\begin{array}{l}\text { Modify the subcatchment schematics. The impervious areas were } \\
\text { routed through a split-flow element (RCHRES element with two } \\
\text { outlets), which separated the portion contributing to the EES } \\
\text { from the overflow/excess flow; the portion draining to the EES } \\
\text { was simulated as an external infiltration to the pervious segment } \\
\text { of the subcatchment. } \\
\text { Apply the same simulation technique as for the EES. } \\
\text { Reduce impervious area to account for pervious pavements. The } \\
\text { Pervious pavements } \\
\text { reduction in impervious area was based upon the paved area } \\
\text { (parking lots and driveways) associated with each land use, as } \\
\text { specified in the Water Quality Model and accounted for 30\% } \\
\text { "void" space afforded by pervious pavements. }\end{array}$ \\
\hline
\end{tabular}


The HSP-F hydrologic model for 2051 uncontrolled land use conditions was revised in order to evaluate the effectiveness of Ecotopia in providing stormwater quantity control, and the model run for a 40 y continuous simulation. The simulated frequency flows for the future land use conditions under this stormwater management strategy are summarized in Table 6.12 and the \% increase compared to 2001 land use conditions are summarized in Table 6.13.

Table 6.12 Frequency flows for 2051 land use conditions with Ecotopia. $\left(\mathrm{m}^{3} / \mathrm{s}\right)$

\begin{tabular}{lcccc}
\hline Damage centre location & \multicolumn{4}{c}{ Frequency (years) } \\
& 10 & 20 & 50 & 100 \\
\hline Upper headwater reaches of Credit River & 21.8 & 26.2 & 32.2 & 36.9 \\
watershed & 71.6 & 82.7 & 94.2 & 101 \\
Middle reaches of Credit River watershed & 114 & 137 & 169 & 194 \\
Lower reaches of Credit River watershed & & & \\
\hline
\end{tabular}

Table $6.13 \%$ Increase in frequency flow 2051 land use conditions with Ecotopia compared with 2001.

\begin{tabular}{lcccc}
\hline Damage centre location & \multicolumn{4}{c}{ Frequency (years) } \\
& 10 & 20 & 50 & 100 \\
\hline Upper headwater reaches of Credit River & 22 & 21 & 20 & 19 \\
watershed & -2 & -7 & -15 & -20 \\
Middle reaches of Credit River watershed & -3 & -3 & -1 & -1 \\
Lower reaches of Credit River watershed & & & \\
\hline
\end{tabular}

The results indicate that the application of Ecotopia in the absence of stormwater quantity control facilities would reduce peak flows at the Damage Centres within the Lower Credit River Watershed to, or below, predeveloped (2001) levels. The peak flows at the Damage Centres within the upper headwater reaches would, nevertheless, remain above the 2001 levels, which suggested that stormwater management techniques, in addition to the aggressive application of infiltration technologies, would be required in order to achieve post-to-pre control at the subwatershed level.

Additional hydrologic analyses were completed in order to evaluate the effectiveness of Ecotopia in combination with "Business As Usual" stormwater quantity controls in-place; as with the previous analyses, this 
assessment has been based upon 2051 land use conditions. The simulated frequency flows for the future land use conditions under this stormwater management alternative are summarized in Table 6.14; the \% increase compared to 2001 land use conditions are summarized in Table 6.15 .

Table 6.14 Frequency flows for 2051 land use conditions with Ecotopia and "business as usual" stormwater management. $\left(\mathrm{m}^{3} / \mathrm{s}\right)$

\begin{tabular}{lcccc}
\hline Damage centre location & \multicolumn{4}{c}{ Frequency (years) } \\
& 10 & 20 & 50 & 100 \\
\hline Upper headwater reaches of Credit River & 13.9 & 17.2 & 22.0 & 25.8 \\
watershed & 71.3 & 82.2 & 93.7 & 101 \\
Middle reaches of Credit River watershed & 109 & 131 & 159 & 181 \\
Lower reaches of Credit River watershed & & & \\
\hline
\end{tabular}

Table 6.15\% Increase in frequency flow 2051 land use conditions with ecotopia and "business as usual" stormwater management versus 2001.

\begin{tabular}{lcccc}
\hline Damage centre location & \multicolumn{4}{c}{ Frequency (years) } \\
& 10 & 20 & 50 & 100 \\
\hline Upper headwater reaches of Credit River & -30 & -28 & -25 & -24 \\
watershed & -2 & -8 & -16 & -20 \\
Middle reaches of Credit River watershed & -8 & -7 & -7 & -7 \\
Lower reaches of Credit River watershed & & & \\
\hline
\end{tabular}

The results of the foregoing assessment indicate that the application of Ecotopia with post-to-pre stormwater quantity controls would reduce peak flow rates at all Damage Centres to, or below, 2001 levels. The results further indicate that the application of Ecotopia with post-to-pre stormwater quantity controls would provide further reductions at the Damage Centres in Orangeville and within the Lower Credit Watershed during the less frequent events, compared to the application of stormwater quantity controls in the absence of Ecotopia; reductions at the Damage Centres within the Middle Credit Watershed associated with the application of Ecotopia with post-topre stormwater quantity controls differ nominally from those associated with the application of Ecotopia alone, thus indicating that the application of post-to-pre quantity controls in addition to the Ecotopia strategy would provide marginal benefit to these Damage Centres. 


\subsection{Conclusions and Recommendations}

As indicated by the foregoing assessment, peak flow rates at the Damage Centres along the Credit River Main Branch, particularly within the Lower Credit River Watershed, would be expected to increase under anticipated future land use conditions. Various stormwater management alternatives are available to control post-development flow rates to pre-development levels along the tributary Subwatersheds outletting to the Credit River Main Branch, which would also reduce the peak flow rates to the Damage Centres along the Credit River Main Branch; nevertheless, increases above existing levels would generally be anticipated. These increases, even when conventional stormwater management strategies are applied, are considered a result of the timing and volume effects associated with the application of conventional stormwater management strategies. Other techniques of separating the times to peak between the Credit River and its tributary subwatersheds within the lower reaches (by over-controlling and undercontrolling peak flow rates, or else providing supplemental flood control) have been investigated and have similarly proven ineffective in fully controlling peak flow rates at the on-line Damage Centres along the lower reaches of the Credit River.

The Ecotopia strategy advanced as part of the Credit River Water Management Strategy Update, in combination with the application of conventional stormwater management for future development, was found to provide the most appreciable reduction in peak flow rates at all Damage Centres along the Credit River Main Branch, and would effectively control post-development flow rates to pre-development levels, as a minimum. Moreover, it has been demonstrated that this strategy, when applied in the headwaters of the Credit River Watershed, would over-control postdevelopment discharge rates to pre-development levels; hence, it would be anticipated that this strategy would result in over-control of peak flow rates along the tributary subwatersheds of the Credit River, and would therefore also satisfy local hydraulic constraints within those areas.

The lot-level controls which comprise the Ecotopia scenario would necessarily require revisions to current Development Standards within the member municipalities in the Credit River Watershed, to allow for the various BMPs (i.e. exfiltration/pervious pipe systems, lot grades less than $1 \%$, depressed curbs and infiltration trenches along road sections, biofilters, and pervious pavements within parking lots and other paved surfaces). Additional revisions would also be required in order to promote Low Impact Development principles and BMPs as part of governing land use planning 
policy on a local and regional scale. As newer technologies and techniques emerge, beyond those assessed under the overall CRWMSU, supporting analyses would be required in order to evaluate and demonstrate the effectiveness and efficiencies afforded by these techniques within the study area.

In order to support and manage the implementation of the foregoing recommendations, the Flow Management Study recommended the formation of Implementation Committees, which would comprise, and be managed by $\mathrm{CVC}$ and respective Municipal Staff. The Implementation Committees would be required to:

- facilitate the revisions to municipal standards and by-laws;

- coordinate with adjacent Authorities (i.e. Toronto and Region Conservation Authority, Conservation Halton, Grand River Conservation Authority) in order to facilitate uniformity of standards throughout the municipalities;

- review the findings of Subwatershed Studies and provide input and direction accordingly; and

- conduct workshops with Development proponents to encourage the application of Low Impact Development practices.

As previously indicated, the future land use scenarios which were evaluated represented the anticipated extent of development. Although sensitivity analyses were completed in order to determine the hydrologic impacts associated with intensification and/or revisions to the anticipated land use condition, the associated land use distribution is nonetheless considered highly speculative at this stage. More detailed and defined land use conditions would therefore need to be developed as part of future Subwatershed Studies; these studies would serve as the mechanism for further refinement and evaluation of stormwater management strategies for future development areas. The Flow Management Study recommended that the future Subwatershed Studies apply the analytical methodologies and techniques developed as part of the overall CRWMSU, as a basis for verifying the impacts of future development, and the alternatives for mitigating anticipated flooding impacts. These alternatives would account for site-specific conditions within the future development areas (i.e. soils, slopes, terrestrial and aquatic constraints) in order to develop a short-list of lot-level controls which would be most appropriate for the proposed 
development area. The models would need to be refined within the limits of the area specific to the Subwatershed Study.

The future Subwatershed Studies also afford an opportunity to refine the analytical techniques which have been applied for the Ecotopia scenario, as additional information and studies become available through future research and monitoring. Other factors influencing flood-risk on a Subwatershed and Watershed basis should also be assessed (e.g. Climate Change), based upon emerging research and techniques.

\section{References}

City of Toronto WWFMMP. January 2003. Snodgrass, W.J. and Watt, C. ed. Credit Valley Conservation. 2001. Integrated Watershed Monitoring Report.

Credit Valley Conservation. April 2007. Credit River Water Management Strategy Update-Making It Work.

Credit Valley Conservation. January 2007. Strategic Plan 2006. Environmental

Water Resources Group. 2001. Travel Time Assessment Model.

Farrell, A., R.B. Scheckenberger and R.T. Guther. 2001. "A Case in Support of Continuous Modeling for Stormwater Management System Design."

Journal of Water Management Modeling R207-07. doi: 10.14796/JWMM.R207-07.

Ontario Ministry of the Environment (MOE). March 2003. Stormwater Management Planning and Design Manual.

Philips Engineering Ltd. September 2007. Credit River Flow Management Study.

Philips Planning and Engineering Limited. 1984. Credit River Flood Damage Reduction Study Volume 1.

Pitt, R.E., Chen, S., Clark, S., Lantrip, J. 2005. "Soil Structure Effects Associated with Urbanization and the benefits of Soil Amendments". Proceedings EWRI ASCE. 2005. Pp. 1-12.

Places to Grow Act. 2005. S.O. 2005, Chapter 13.

Triton Engineering. 1990. Credit River Water Management Strategy.

Zimmer, C. May 2006. Thesis. 
